\title{
Central nervous system vasculopathy and Seckel syndrome: case illustration and systematic review
}

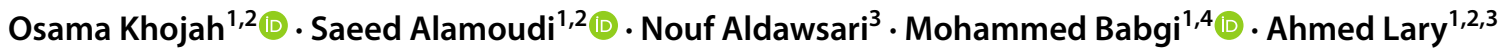

Received: 3 March 2021 / Accepted: 30 June 2021 / Published online: 3 August 2021

(c) The Author(s) 2021

\begin{abstract}
Purpose To systematically review reported cases of Seckel syndrome (SS) and point out cases associated with central nervous system (CNS) vasculopathy and provide a summary of their clinical presentation, management, and outcomes including our illustrative case.

Methods We conducted a search on the MEDLINE, PubMed, Google Scholar, and Cochrane databases using the keywords "Seckel+ syndrome." We identified 127 related articles reporting 252 cases of SS apart from our case. Moreover, we searched for SS cases with CNS vasculopathies from the same databases. We identified 7 related articles reporting 7 cases of CNS vasculopathies in SS patients.

Results The overall rate of CNS vasculopathy in SS patients is $3.16 \%(n=8 / 253)$, where moyamoya disease (MMD) accounted for $1.97 \%$. The mean age is 13.5 years (6-19 years), with equal gender distribution (M:F, 1:1). The most common presenting symptoms were headache and seizure followed by weakness or coma. Aneurysms were mostly located in the basilar artery, middle cerebral artery, and internal carotid artery, respectively. Regardless of the management approach, 50\% of the cases sustained mild-moderate neurological deficit, $37.5 \%$ have died, and $12.5 \%$ sustained no deficit.

Conclusion A high index of suspicion should be maintained in (SS) patients, and MMD should be part of the differential diagnosis. Prevalence of CNS vasculopathy in SS is 3.16\% with a much higher prevalence of MMD compared to the general population. Screening for cerebral vasculopathy in SS is justifiable especially in centers that have good resources. Further data are still needed to identify the most appropriate management plan in these cases.
\end{abstract}

Keywords Bird-headed dwarfism · Cerebrovascular disorders · Intracranial aneurysm · Microcephalic osteodysplastic primordial dwarfism · Type II · Moyamoya disease $\cdot$ Seckel syndrome

\section{Introduction}

Microcephalic primordial dwarfism (MPD) is a rare form of intrauterine growth retardation (IUGR), which leads to postnatal dwarfism. MPD is a group of disorders that includes Seckel syndrome (SS), microcephalic

Osama Khojah

osamakhojah001@gmail.com

1 College of Medicine, King Saud Bin Abdulaziz University for Health Sciences, Jeddah, Saudi Arabia

2 King Abdullah International Medical Research Center, Jeddah, Saudi Arabia

3 King Abdulaziz Medical City, National Guard Health Affairs, Jeddah, Saudi Arabia

4 Division of Neurosurgery, King Abdulaziz University Hospital, Jeddah, Saudi Arabia osteodysplastic primordial dwarfism (MOPD), and MeierGorlin syndrome which occur due to embryonic abnormalities [1,2]. SS (or bird-like dwarfism) is an autosomal recessive microcephalic primordial dwarfism, affecting almost 1 out of 10,000 children with no gender predilection [3]. Few reports of SS have linked the disease with multiple central nervous system (CNS) pathologies such as intracranial aneurysms or severe hypertension resulting in cerebrovascular accidents, agenesis of the corpus callosum, cortical dysplasia, and moyamoya disease (MMD) [4-7]. We report a case of SS that was complicated with aneurysmal subarachnoid hemorrhage and was found to have MMD. Also, we are conducting a systematic review to focus on the clinical association and prevalence of CNS vasculopathy in SS, and their presentations, management, and outcomes. 


\section{Methods}

\section{Literature review}

\section{Search methods}

We performed a comprehensive systematic review using the following keywords: "Seckel+ syndrome" searching the MEDLINE, PubMed, Google Scholar, and Cochrane databases. It was conducted based on Preferred Reporting Items for Systematic Reviews and Meta-Analyses (PRISMA) guidelines. From the list of all reported cases, we looked for cases that reported CNS vasculopathies. To ensure that the list is comprehensive, we performed a comprehensive systematic review using the following keywords: "Seckel," "Cerebrovascular disease," "Vascular disorders," "Aneurysms," and "Moyamoya," as MeSH and keywords in combination with Boolean operators to ensure inclusivity of all possible results. This too was conducted based on Preferred Reporting Items for Systematic Reviews and Meta-Analyses (PRISMA) guidelines. In addition, we identified candidate studies from the reference list of the eligible studies (Fig. 1).

\section{Inclusion and exclusion criteria}

SS was first reported in 1959; hence, all studies published from 1959 until May 15, 2021, which reported at least one case of SS, were included [8]. Only studies which were conducted in English or translated to English were included. Prenatal and autopsy diagnoses of SS as well as historical cases which were not confirmed were excluded. Furthermore, we assessed SS cases which reported CNS vasculopathies. Magnetic resonance angiography (MRA), digital
Fig. 1 PRISMA diagram depicting the literature search strategy
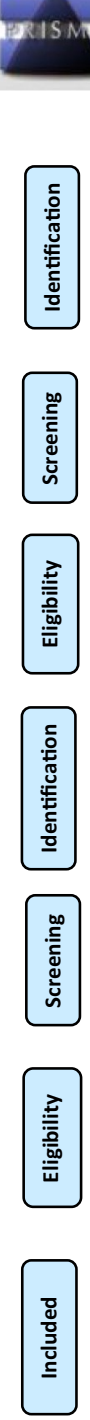

\section{PRISMA 2009 Flow Diagram}

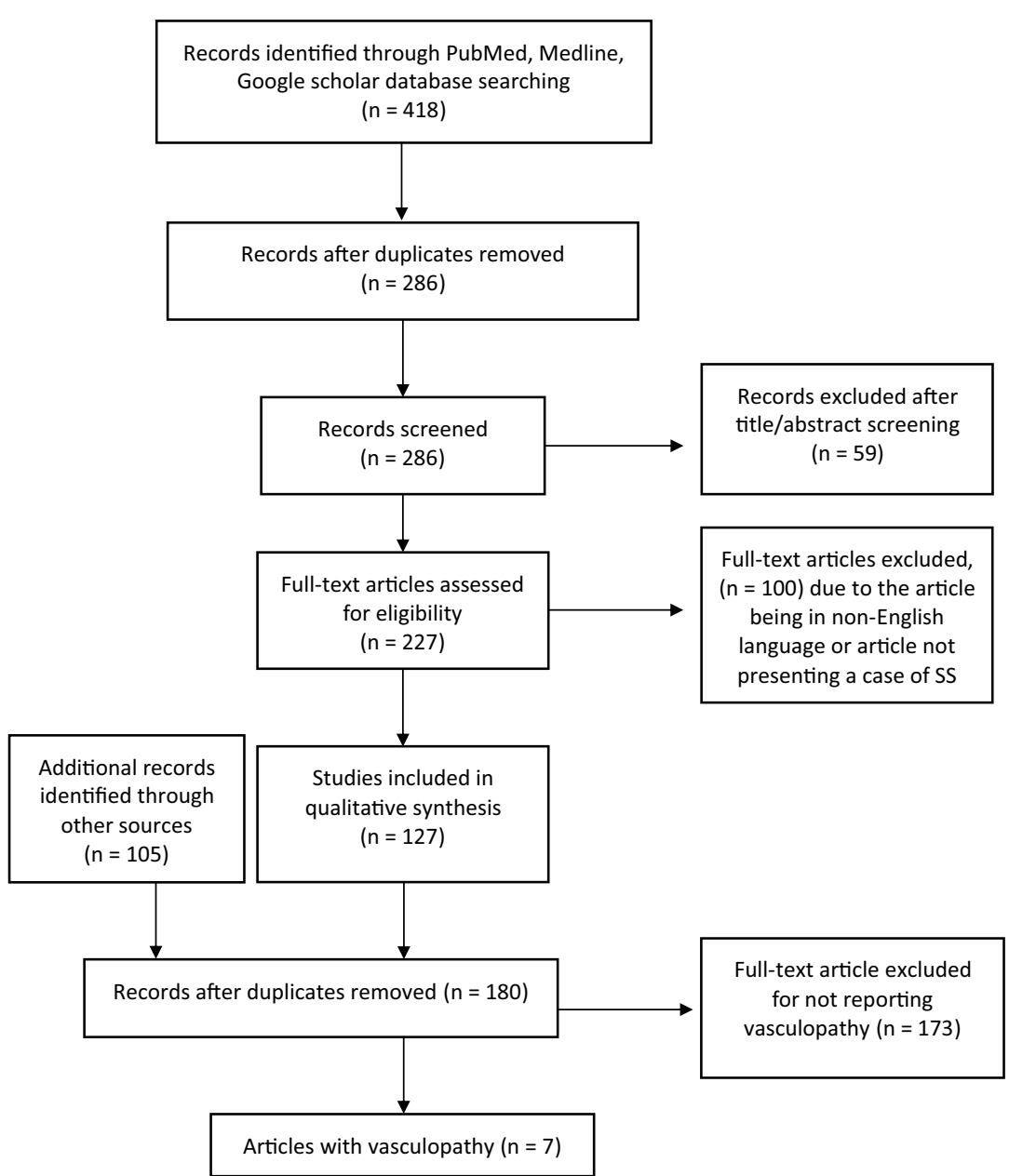


subtraction angiography (DSA), cerebral angiogram (CTA), or autopsy findings were considered acceptable manners of diagnosing intracerebral vascular diseases. We considered digital subtraction angiography (DSA) as the diagnostic investigation for diagnosing MMD. However, the MRA and CTA findings provided by Inaloo et al. were considered acceptable to make the MMD diagnosis [128]. We have also assessed SS cases which reported CNS anomalies. The assessment was based on imaging of brain or autopsy findings of the brain if no imaging was performed.

\section{Selection of studies}

Two of the reviewers (OK and SA) independently assessed the potential eligibility of each of the articles found through the database search. Determining the eligibility of the article was done through screening title/abstract then reviewing the full-text versions of the articles. All disagreements were resolved by a consensus, and by arbitration by a third reviewer (NA).

\section{Data collection}

The data collected from each eligible article included the number of SS patients, the presence of a CNS anomaly, and the presence of a CNS vasculopathy. From articles which reported CNS vasculopathy, demographic data, clinical presentation, type of vasculopathy, Suzuki grading if the reported vasculopathy was MMD, treatment, surgical complications, and clinical outcomes were collected.

\section{Study objectives}

The primary objectives of the study were (1) to review all the published literature pertaining to SS and (2) to review the cases of SS and vasculopathies by evaluating the clinical presentations, imaging results, treatment methods, and clinical outcomes.

The secondary objectives of the study were (1) to evaluate the proportions of CNS anomalies in SS, (2) to evaluate the proportions of vasculopathies and MMD in SS, and (3) to report a patient with SS and MMD.

\section{Quality assessment}

Two reviewers (OK and SA) independently critically appraised the methodologic quality of the studies by using the modified tool suggested by Murad et al. [127]. This assessment aims to evaluate the risk of bias of the case reports and case series. We adapted this tool to assess the reported CNS vasculopathies in SS patients. Out of the 8 questions described in this tool, 5 questions were deemed compatible with our design and adjusted to fit our population. Each question can be answered with "Yes" or "No" after critically appraising each study. Studies were appraised based on the following: (1) if the study was specifically conducted to assess SS patients; (2) if the exposure of SS patients to treatment such as conservative treatment, pial synangiosis, endovascular treatment, or surgical clipping adequately ascertained; (3) if the outcome of SS patients with a vasculopathy, whether clinically or radiologically, is adequately ascertained; (4) if the SS patients were followed up for enough time for outcomes such as ischemic strokes, rebleeding, or re-rupture to occur; and (5) if the study was described with enough details for replication by another investigator or to allow other investigators to make an inference. A study was considered as high quality if it scored "Yes" in more than three questions, moderate quality if it scored "Yes" in two or three questions, and low quality if it scored "Yes" in one or none of the questions. All disagreements were resolved by a consensus, and by arbitration by a third reviewer (MB) (Supplementary table 1).

Ethical considerations This study was approved by the Institutional Review Board at King Abdullah International Medical Research Centre (KAIMRC) with reference number: JED-21-427780-13450.

\section{Results}

\section{Case illustration}

This is an 8-year-old male patient, who is the second child of consanguineous parents, a product of preterm (26 weeks), and admitted to a neonatal intensive care unit (NICU) for 4 months. The patient, who is a known case of SS, presented to the emergency department with two episodes of tonic-clonic seizures, $20 \mathrm{~min}$ apart, and lasting for 10-15 min each, $2 \mathrm{~h}$ after a minor fall without losing consciousness, after which he resumed his activities.

Upon examination, the patient was drowsy, and difficult to examine. He had a GCS of 11/15 (Eye 3/4, Verbal 3/5, Motor $5 / 6$ ), pupils were $3 \mathrm{~mm}$ in size and reactive to light bilaterally, and he was able to move all limbs. Physical dysmorphic features were noted including microcephaly, microphthalmia, micrognathia, depressed nasal bridge, coloboma, and small hands and feet (Fig. 2). Urgent computed tomography (CT) of the brain showed evidence of significant subarachnoid hemorrhage (Fig. 3). The patient was admitted to the pediatric intensive care unit (PICU) for close observation. The patient underwent computed tomographic angiography (CTA) that demonstrated complete absence of flow in bilateral internal carotid arteries, as well as a basilar tip saccular aneurysm measuring $9 \times 5 \mathrm{~mm}$ in maximum dimension (Fig. 4), and he was opted for endovascular management. 
Fig. 2 This is a scout image featuring the dysmorphic characteristics including micrognathia, beak-like nose, and receding forehead
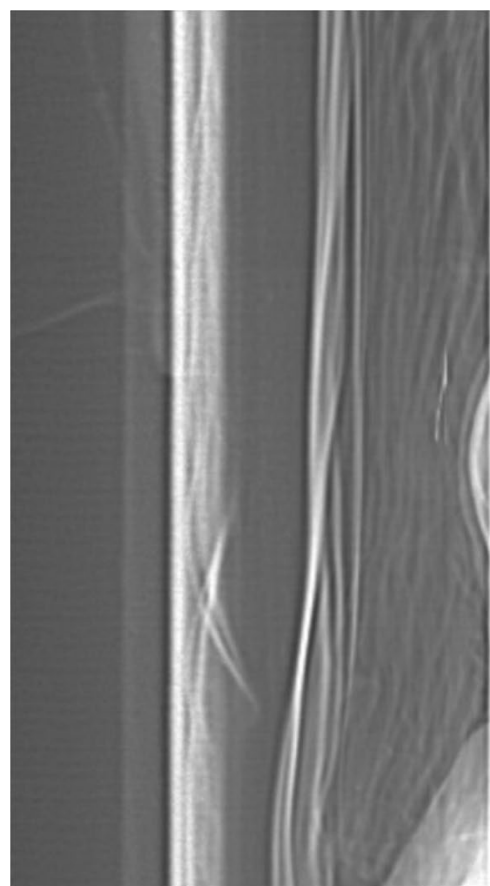

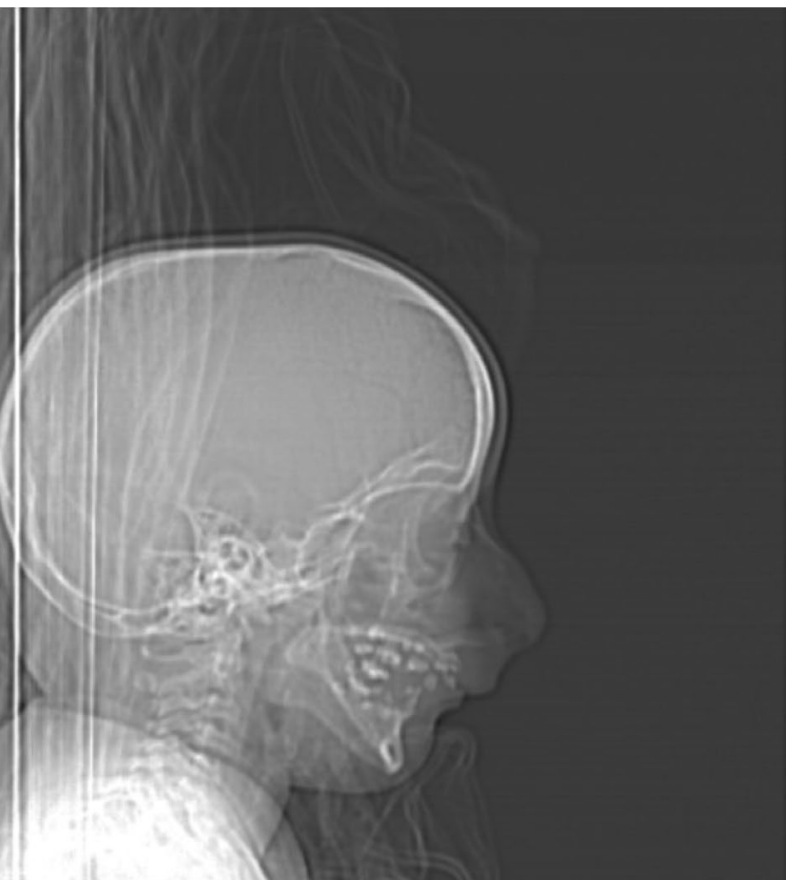

On day 2, digital subtraction angiography (DSA) was done and a clear demonstration of MMD was visualized (Fig. 5). The patient underwent endovascular coiling of the basilar tip aneurysm with 9 coils leaving a minor filling residual of the sac; the procedure showed bilateral patency of the posterior cerebral arteries with no intraprocedural complications (Fig. 5). Shortly after returning to the PICU, the patient suddenly deteriorated, and urgent CT showed a significant interval increase in the subarachnoid hemorrhage with hydrocephalus associated with diffuse brain edema suggesting a rebleed of the aneurysm (Fig. 6). During the following day, despite maximal medical management and the patient was declared dead.

\section{Systematic review}

After reviewing 418 articles, 286 articles were excluded as duplicates, and 59 of articles were excluded based on screening the titles or the abstracts. One hundred articles were excluded after reading full texts for not fulfilling the inclusion criteria. One hundred twenty-seven articles identified at least one SS case with the total number of SS patients being 252 patients [3-126]. Out of these articles, 7 reported a CNS vasculopathy in association with SS fulfilling the specified criteria (Fig. 1).

Forty-eight articles reported CNS anomalies, of which 7 articles reported CNS vasculopathies (aneurysm and/
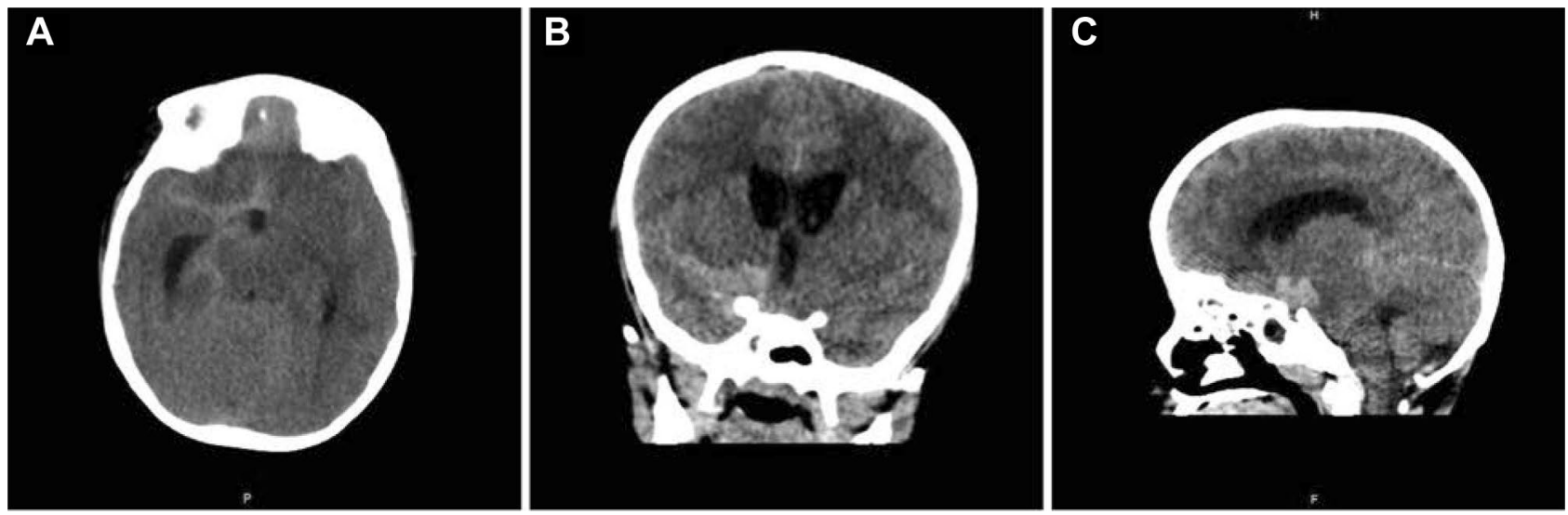

Fig. 3 This is the initial computerized tomography (CT) scan with axial, coronal, and sagittal views demonstrating the basal subarachnoid hemorrhage (A-C) 
Fig. 4 These are computerized tomography angiography (CT-A) axial, sagittal, and coronal images demonstrating the basilar tip aneurysm with an abnormal background of heavy collaterals (A-C); the basilar tip aneurysm has a multi-lobulated configuration illustrated in the three-dimensional image (D)
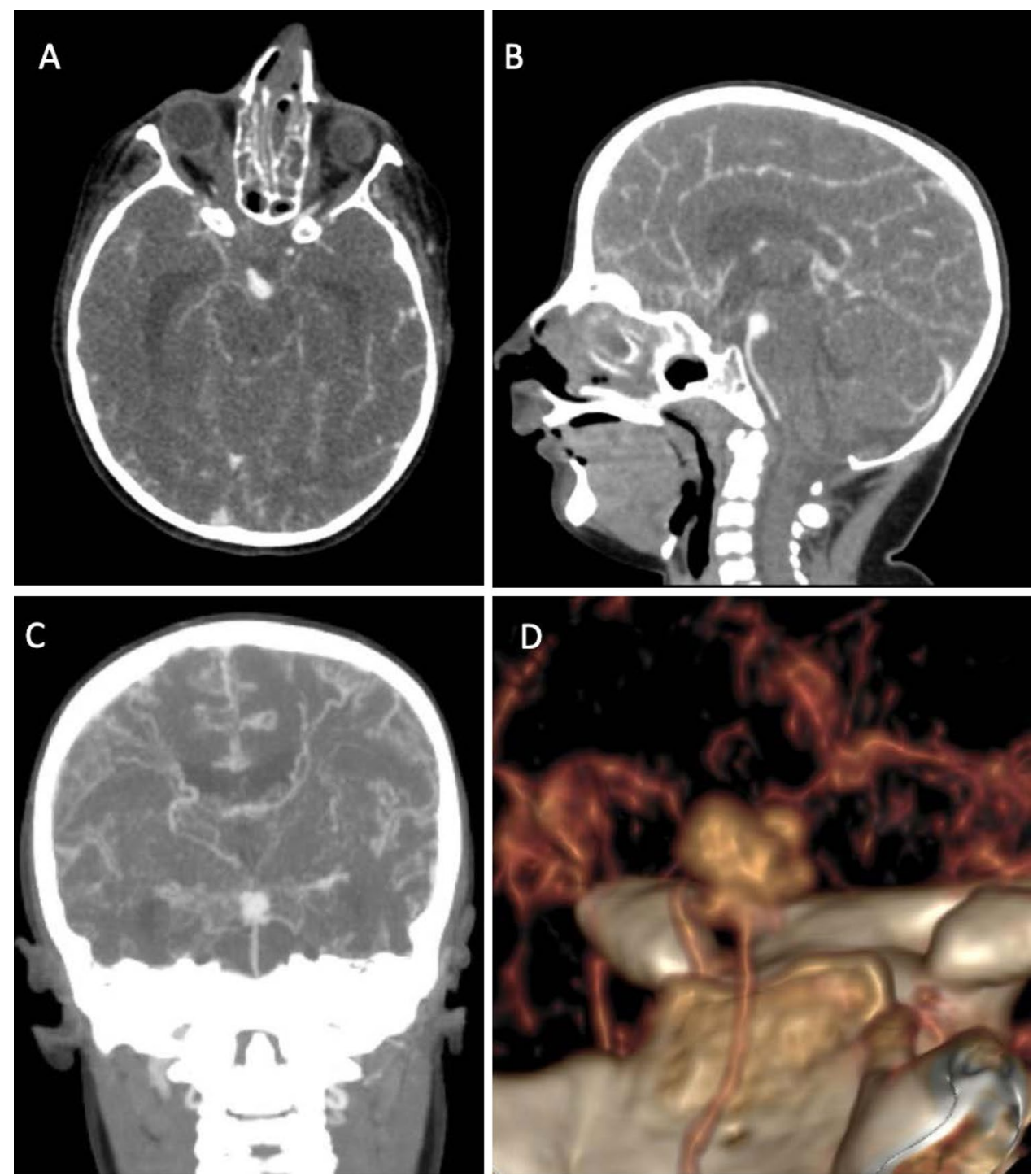

or MMD). Including our case ( $\mathrm{n}=70 / 253), 27.67 \%$ of SS cases reported the presence of CNS anomalies including arterial aneurysms, vasculopathy, hematomas, clots, agenesis of corpus callosum, cysts, hypoplastic cerebrum or cerebellum, pachygyria, and herniations. The 7 articles reporting CNS vasculopathy in SS patients were extracted for further data analysis. After adding our case, the overall rate of CNS vasculopathy in SS patients is $3.16 \%(\mathrm{n}=8 / 253)$, where MMD accounted for $1.97 \%$ $(\mathrm{n}=5 / 253)$. Aneurysms were mostly located in the basilar artery $(50 \%)$, middle cerebral artery $(37.5 \%)$, or the internal carotid artery (25\%). Regardless of the management approach, $50 \%(n=4 / 8)$ of the cases sustained mildmoderate neurological deficit, $37.5 \%(n=3 / 8)$ died, and $12.5 \%(\mathrm{n}=1 / 8)$ sustained no deficit (Table 1$)[3-7,50$, 127].

\section{Literature review}

\section{Demographic data and clinical presentations}

A total of 8 cases with SS have been identified in literature that is associated with CNS vasculopathy, including our illustrative case (Table 1). The mean age of diagnosis was 13.25 (range 6-19) years with equal gender distribution (M:F, 1:1). Most common symptoms/presentations were headache $(37.5 \%)$, seizure $(37.5 \%)$, followed by weakness $(25 \%)$, or coma (25\%). All but one patient $(87.5 \%)$ were found to have cerebral aneurysms either isolated or with a background of MMD. MMD was diagnosed in $62.5 \%$ of the patients. All patients were diagnosed due to complications of their disease rather than being diagnosed as a part of screening. 

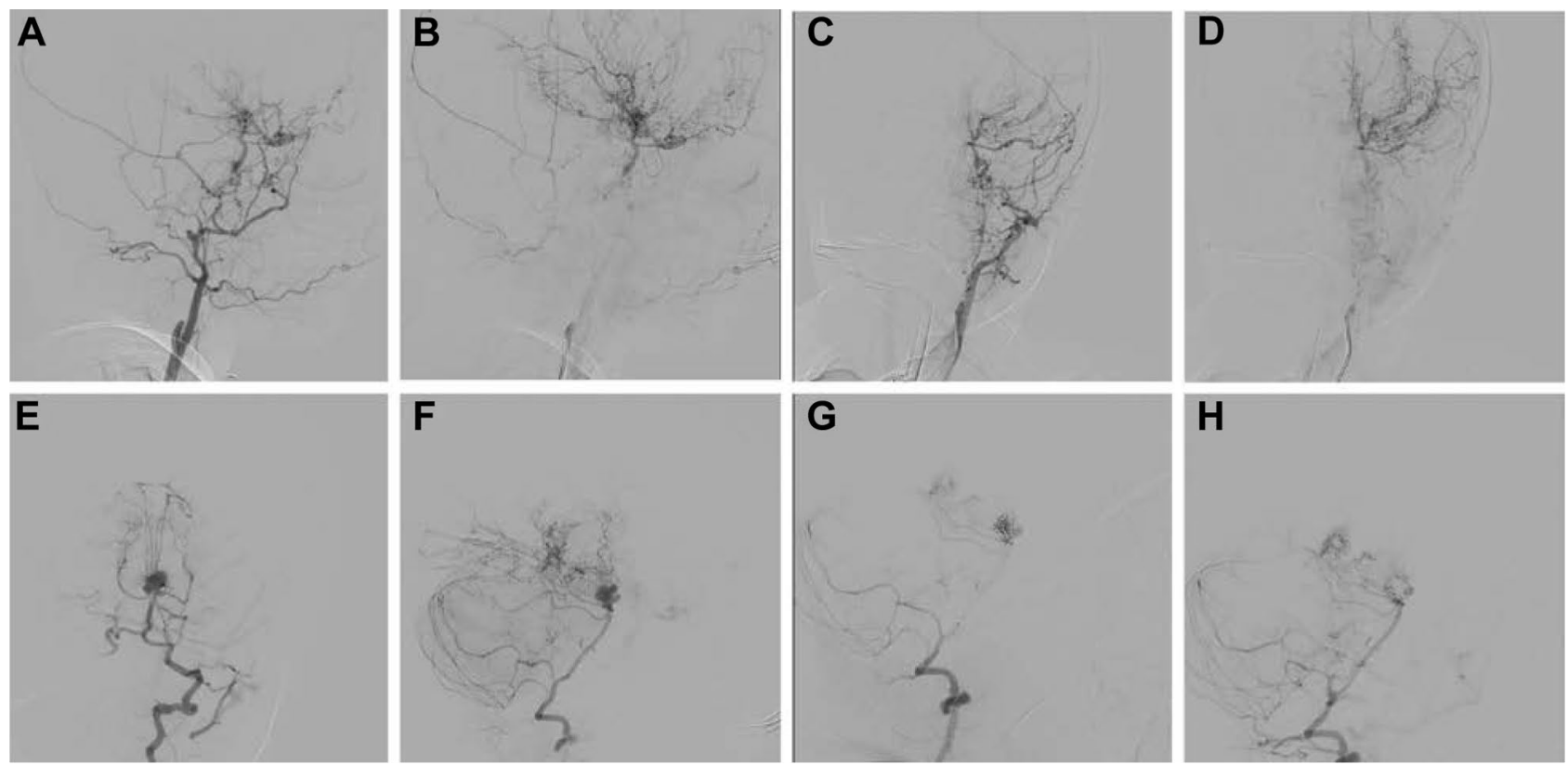

Fig. 5 This is a digital subtraction angiography (DSA) lateral projection after right internal carotid injection showing complete occlusion with contrast reflux to right external carotid and its intracranial collaterals along with moyamoya features $(\mathbf{A}, \mathbf{B})$ with similar findings

Codd et al. reported the first case in 2009 which draws the attention toward the possible association between SS and MMD. Of the cases reported to have both SS and MMD, three presented with signs of cerebral ischemia including unilateral weakness, numbness, facial drooping, and inability to walk, whereas 1 case presented with convulsions $[3,5,50,128]$.

\section{Vasculopathy characteristics}

All SS patients with MMD had bilateral pathology with no predilection to a specific severity grade. Suzuki grading of

in the left side with posteroanterior (PA) views $(\mathbf{C}, \mathbf{D})$; right vertebral artery injection with ipsilateral oblique view in $(\mathbf{E})$, and projection demonstrating the multi-lobulated basilar tip aneurysm before, during and after coiling $(\mathbf{F}-\mathbf{H})$

MMD in SS patients was reported in 2 cases, Codd et al. reported a Suzuki stage of III, and Inaloo et al. reported a mild stage of I-II. In our case, conventional subtraction angiography confirmed the diagnosis with a Suzuki grade of IV. Majority (71.4\%) of SS with aneurysms had posterior circulation involvement [128].

\section{Management and outcomes}

A single case of SS with aneurysm, reported by D'Angelo et al. was managed with clipping. The remaining patients in this group were managed either with endovascular control
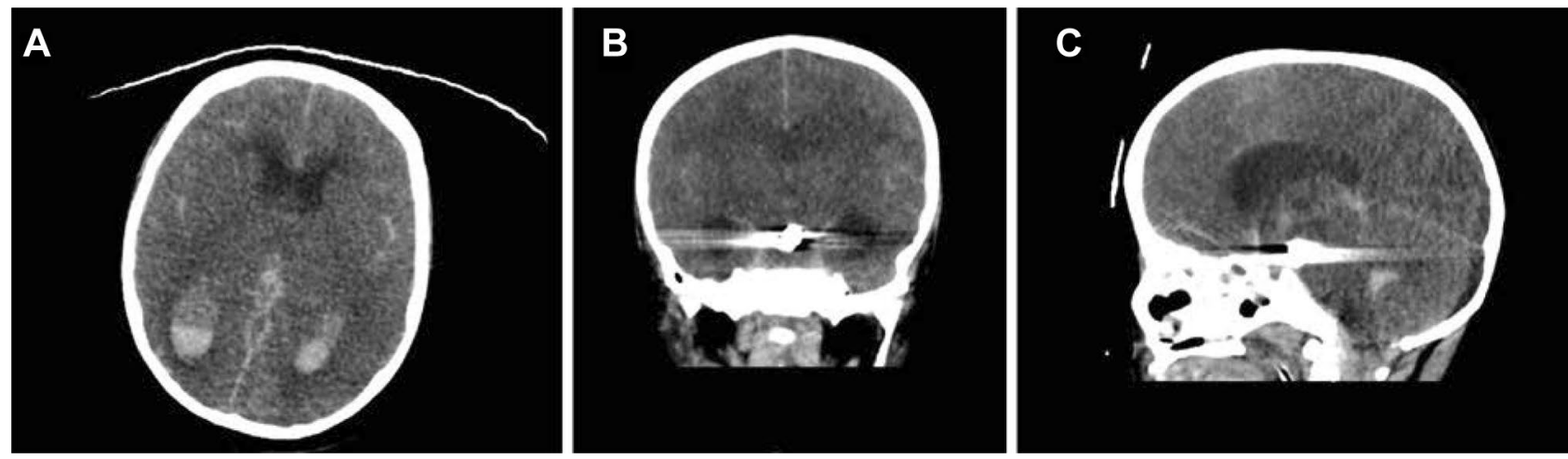

Fig. 6 These are computerized tomography (CT) images after the sudden deterioration of the patient, showing intraventricular hemorrhage and further spread of the subarachnoid hemorrhage with hydrocephalus and significant edema (A-C) 


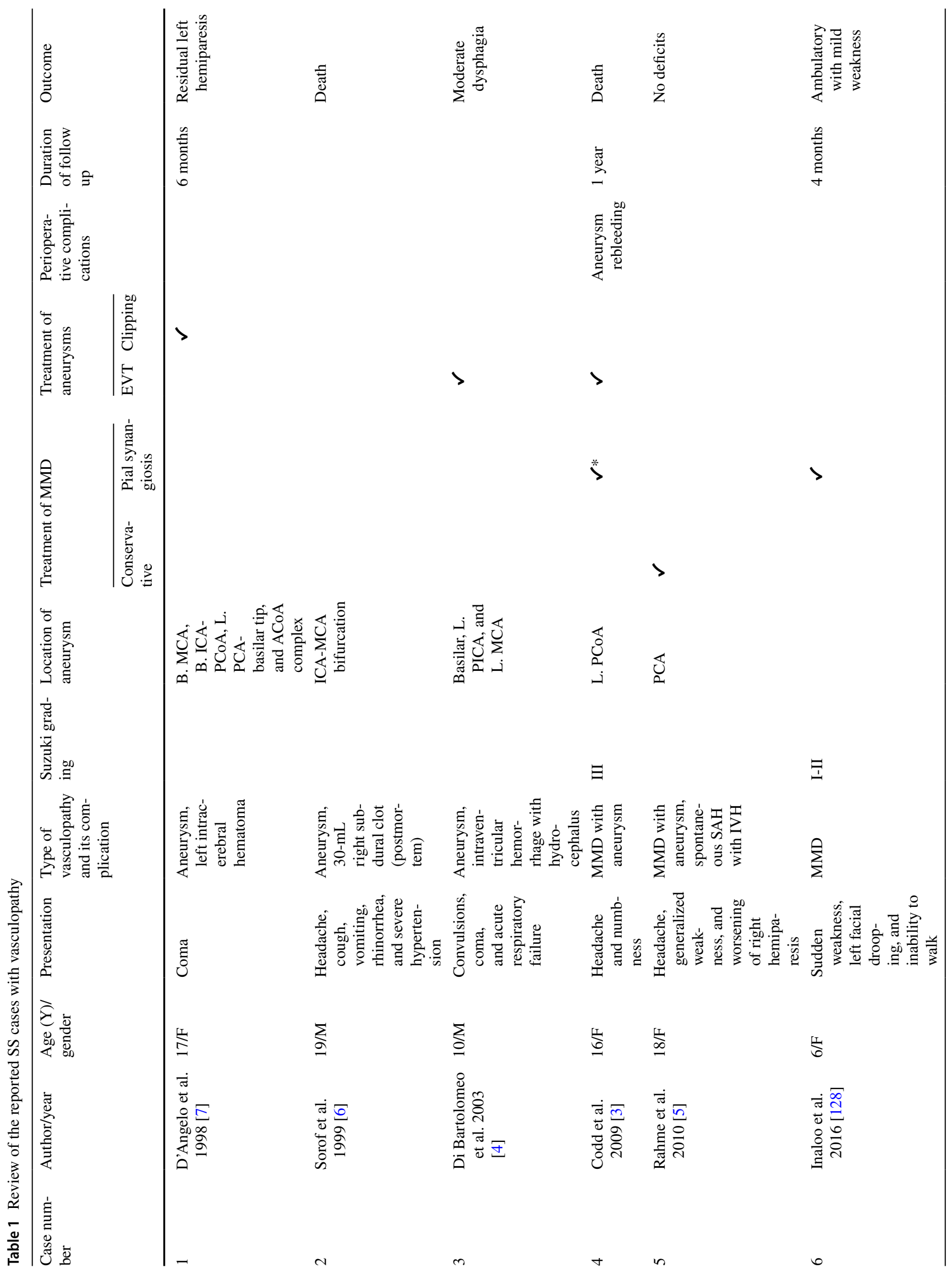




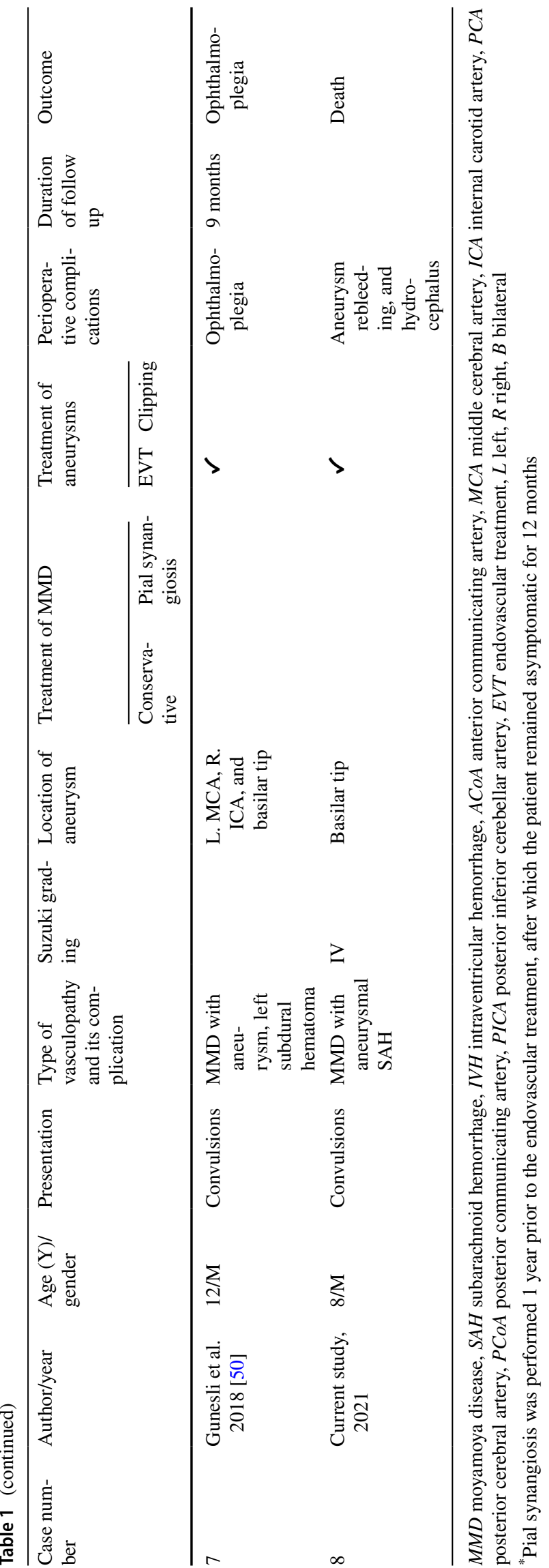

or conservatively. Three patients (37.5\%) of SS with CNS vasculopathy died from disease, two of which were due to aneurysmal rebleeding following endovascular intervention $[3-7,50,128]$.

\section{Discussion}

SS was first reported in 1959 by Mann and Russell and later described in detail by Seckel in 1960. It is characterized by short stature, microcephaly, moderate-to-severe mental retardation, cryptorchidism, and facial abnormalities [8, 130]. Dysmorphic features include, but are not limited to, a receding forehead, narrow face, large eyes, large beak-like protrusion of the nose, and micrognathia. On top of these distinct physical features, our case was confirmed to have SS via molecular testing and presence of PCNT mutation. PCNT gene mutations are typically indicative of MOPD II; however, it has been reported to be present in SS patients as well. Willems et al. noticed that SS patients who have PCNT mutation seem to have more severe growth retardation than those who do not have the gene mutation ( -6 to -8 SD vs. -4 to $-5 \mathrm{SD}$ ) [131]. It is important to note that MOPD II is frequently misdiagnosed as SS due to the similarities between them. Moreover, correctly diagnosing SS becomes especially difficult when the patient does not present with all of the features of SS [132]. One way to differentiate is to examine the proportionality as SS exhibits proportionate growth retardation and MOPD II exhibits disproportionate growth retardation [66].

MMD is a rare chronic occlusive cerebrovascular disease which is characterized by unilateral or bilateral progressive narrowing of the circle of Willis as well as abnormal system of blood vessels at the base of the brain $[129,133]$. Suzuki and Takaku were the first to describe MMD in 1969 as small, basal, and collateral vessel formation in a patient with bilateral occlusion of the internal carotid arteries which showed the appearance of a puff of smoke on imaging [134]. MMD seems to have a bimodal distribution with the first peak occurring around the age of 10 years and the other around the age of 30-40 years. Although this syndrome has a higher incidence in individuals of Asian descent, it is increasingly recognized throughout the world, with a prevalence of 3 cases per 100,000 children in Japan and 0.086 cases per 100,000 persons in America [133, 134]. In comparison to the number of MMD cases in SS that we estimated, the number of MMD in these populations is drastically lower. MMD has been linked to other conditions like atherosclerosis, autoimmune diseases, meningitis, sickle cell anemia, and trisomy 21. Also, MMD patients generally have a higher incidence of aneurysm formation in the posterior cerebral circulation $[3,127,135]$. The gold standard for diagnosis and evaluation of MMD is digital subtraction angiography [50]. 
Particularly in pediatrics and patients with MPDs, like SS, cerebral ischemia is the most often encountered clinical presentation of MMD [3, 128, 140]. The etiology in our patient was an aneurysmal subarachnoid hemorrhage (SAH) from the basilar tip aneurysm that caused convulsions, on a background of advanced MMD. Posterior circulation aneurysm formation in MMD is a reported risk due to the high flow pressure shifted especially at the basilar tip, and this is clearly demonstrated in SS patients (Table 1). Pediatric cerebral aneurysms are a relatively uncommon encounter in clinical practice as reports suggest an incidence between 3 and $4 \%$, which translates to roughly $1-3$ cases per 1 million population [136]. The majority of cases present within the first 2 years of life with a peak in the first 6 months after birth [136]. These early childhood lesions typically arise in the vertebrobasilar system and along the middle cerebral artery $[136,137]$. The presence of multiple aneurysms in this age group is rare, accounts for around 5\% of cases, and is typically associated with other factors such as prior cranial irradiation, MMD, sickle cell disease, and arteriovenous malformations [136]. SAH is the most common initial presentation for cerebral aneurysms [136, 138]. Medical management should be initiated immediately to prevent secondary complications such as rebleeding and to restore hemodynamic stability [136]. Surgical options include aneurysm neck occlusion or ligation, occlusion of the carrying artery of aneurysm, aneurysm wrapping with muscle, aneurysm resection, or carotid artery ligation [137]. Both surgical and endovascular management showed good outcomes; however, endovascular management requires close monitoring to detect any aneurysmal propagation especially with such long-life expectancy [137].

Numerous reports have indicated the association between various phenotypes of microcephalic dwarfism and cerebrovascular lesions, both occlusive and aneurysmal [139, 140]. A 2013 review of all reported cases of MOPD II to establish an evidence-based screening approach found that the frequency of cerebrovascular lesions in this subset of patients to be approximately $44 \%$ (95\% CI 19-52\%), not far from an earlier reported frequency of 52\% [139, 140]. Additionally, younger children tend to present with occlusive arteriopathy while older patients have aneurysms $[3,139,141]$. A proposed recommended screening approach is to initiate screening at time of diagnosis using magnetic resonance imaging (MRI) and magnetic resonance angiography (MRA) of the circle of Willis and cervical arteries. MRA is preferred for screening as it spares patients from the risk of intracranial hemorrhage and adverse consequences of more invasive modalities $[139,140]$. Considering the uncertainty about the development and progression of cerebrovascular lesions in this population, screening should be performed early and frequently. Imaging should be on a yearly interval up to 10 years of age and thereafter widened to every 2 years with the goal of detecting aneurysms. Current data suggest this approach to be lifelong. This tactic is supported by a large dataset, high rate of cerebrovascular anomalies among this population, adverse outcomes if left untreated, and the potential of early detection and prophylactic treatment to improve long-term outcomes [139, 140]. We believe that such a screening should also be applied to patients with SS, giving the relative similarities between both syndromes, and the recent appreciation of increased rate of neurovascular anomalies is SS compared to the normal population. We agree with Perry et al., and we favor the use of MRA as a screening tool as it spares patients from the risk of contrast, radiation associated with DSA and CTA, and adverse consequences of more invasive modalities. This is also supported by a recent systematic review paper discussing the intracranial aneurysms in all MPD patients, inclusive of SS [142].

Management of MMD is aimed to improve perfusion of the affected region of the brain. This improvement has the potential of reducing risk of future stroke as well as mitigating symptoms $[3,127]$. Conservative medical treatment is used when the patient is deemed high risk for invasive procedures or in case the condition is mild [143]. Since the pathology of MMD spares the external carotid artery, it is typically used as a source of new blood flow either directly or indirectly [3, 143]. Direct revascularization involves the anastomoses of a branch of the external carotid directly to a cortical artery. On the other hand, indirect revascularization is achieved by promoting new vessel formation by placing a tissue perfused by the external carotid in direct contact with the brain $[135,143]$. A review of 143 children who underwent pial synangiosis demonstrated that perioperative stroke frequency was reduced from $67 \%$ down to $3.2 \%$ after $\geq 1$ year postoperatively $[135,143]$. Open surgical revascularization is technically difficult in children given the small size of anastomosed vessels. This is clearly further aggravated in cases of microcephalic dwarfism [143, 144]. Additionally, patients with microcephalic dwarfism should be treated akin to infantile patients as their cerebral autoregulation is underdeveloped [129]. The paucity of evidence on the optimum management approach along with the associated comorbidities that impact outcomes in these patients warrants a case-by-case approach to management. Additional studies are needed to delineate the difference in outcomes, or lack thereof, between different treatment modalities.

Our review for the management of MMD associated with SS was managed conservatively only once and was managed by indirect revascularization twice. Both cases managed surgically had favorable outcomes as one was treated with encephalomyosynangiosis and demonstrated reasonable recovery after 4 months with residual weakness in right lower extremity while the other was managed with pial synangiosis and had reasonable outcome at 1-year follow-up (asymptomatic, no headache, or transient ischemic attack (TIA)) [3, 5, 
$50,127]$. This data, although small in number, carries support to manage MMD cases surgically early in the course in order to reduce the morbidity. Prevention of aneurysm formation by this intervention is a valid question that requires large prospective studies that are still lacking. However, a 10-year prospective study for patients with aneurysms coexistent with MMD reported benefit from surgical revascularization to indirectly treat peripherally located aneurysms [145].

In the case of SS-associated aneurysms, our review included a single case with surgical clipping that resulted in relatively good recovery and aneurysm control. The other four cases (including our case) were managed endovascularly with acceptable outcomes in 2 cases (50\%), and rebleeding causing death in the remaining two cases (50\%). There were a total of three cases of SS-associated aneurysms with a background of confirmed MMD and were all managed endovascularly with 2 out of 3 cases resulting in a rebleeding and death (Table 1). With such small number of cases, a predilection of the appropriate treatment methodology is difficult to be drawn, although endovascular intervention for aneurysms in MMD in this review reflected discouraging results. Case-by-case decision making seems most appropriate until further pooling of data is reported with this context of co-existing pathologies.

\section{Limitations}

Considering the retrospective nature of reports included in this review, publication bias is an unavoidable limitation to this review. The inconsistent reporting of several variables such as aneurysm morphology, treatment plan, and outcomes may also hinder the ability to make conclusions regarding the optimum management of this patient population. A key limitation to this review was the language barrier that impeded the authors' capacity to evaluate reports written in languages other than English, of which there were many. Republication in which the same case was reported multiple times may have introduced bias as well. Epidemiological data are difficult to be concluded for such a rare entity; we understand that using cohort studies is the best way to infer these statistics. However, in our case, we tried to pool all the cases of SS and report a representative estimate of the prevalence for vasculopathies in SS. Nevertheless, it is our belief that this review provides an outline that could inspire additional exploration of the association between SS and CNS vasculopathy.

\section{Conclusion}

High index of suspicion should be maintained in SS patients, especially when presenting with focal neurological deficits, and MMD should be part of the differential diagnosis. Prevalence of CNS vasculopathy in SS is $3.16 \%$ with a much higher prevalence of MMD compared to the general population. Screening for cerebral vasculopathy in SS is justifiable especially in centers that have good resources. Further data are still needed to identify the most appropriate management plan in these cases.

Supplementary information The online version contains supplementary material available at https://doi.org/10.1007/s00381-021-05284-8.

Author contribution AL and MB made substantial contributions to the conception or design of the research. OK and SA made substantial contributions to the acquisition, analysis, and interpretation of data. All authors drafted the work or revised it critically for important intellectual content. $\mathrm{OK}, \mathrm{SA}$, and MB made substantial contributions to the methodologic quality assessment of the literature. All authors approved the version to be published. All authors agreed to be accountable for all aspects of the work in ensuring that questions related to the accuracy or integrity of any part of the work are appropriately investigated and resolved.

\section{Declarations}

Ethics approval This study was approved by the Institutional Review Board at King Abdullah International Medical Research Centre (KAIMRC) with reference number JED-21-427780-13450 obtained on January 28,2021 . This study was performed in line with the principles of the Declaration of Helsinki.

Conflict of interest The authors declare no competing interests.

Open Access This article is licensed under a Creative Commons Attribution 4.0 International License, which permits use, sharing, adaptation, distribution and reproduction in any medium or format, as long as you give appropriate credit to the original author(s) and the source, provide a link to the Creative Commons licence, and indicate if changes were made. The images or other third party material in this article are included in the article's Creative Commons licence, unless indicated otherwise in a credit line to the material. If material is not included in the article's Creative Commons licence and your intended use is not permitted by statutory regulation or exceeds the permitted use, you will need to obtain permission directly from the copyright holder. To view a copy of this licence, visit http://creativecommons.org/licenses/by/4.0/.

\section{References}

1. Khetarpal P, Das S, Panigrahi I, Munshi A (2016) Primordial dwarfism: overview of clinical and genetic aspects. Mol Genet Genomics MGG 291:1-15. https://doi.org/10.1007/s00438-015-1110-y

2. Hall JG, Flora C, Scott CI et al (2004) Majewski osteodysplastic primordial dwarfism type II (MOPD II): natural history and clinical findings. Am J Med Genet A 130A:55-72. https://doi.org/10. 1002/ajmg.a.30203

3. Codd PJ, Scott RM, Smith ER (2009) Seckel syndrome and moyamoya. J Neurosurg Pediatr 3:320-324. https://doi.org/10.3171/ 2008.12.PEDS08205

4. Di Bartolomeo R, Polidori G, Piastra M et al (2003) Malignant hypertension and cerebral haemorrhage in Seckel syndrome. Eur J Pediatr 162:860-862. https://doi.org/10.1007/s00431-003-1310-z

5. Rahme R, Crevier L, Dubois J, Mercier C (2010) Moyamoyalike vasculopathy and Seckel syndrome: just a coincidence? 
Childs Nerv Syst ChNS Off J Int Soc Pediatr Neurosurg 26:983-986. https://doi.org/10.1007/s00381-010-1142-x

6. Sorof JM, Dow-Smith C, Moore PJ (1999) Severe hypertensive sequelae in a child with Seckel syndrome (bird-like dwarfism). Pediatr Nephrol Berl Ger 13:343-346. https://doi.org/10.1007/ s004670050623

7. D'Angelo VA, Ceddia AM, Zelante L, Florio FP (1998) Multiple intracranial aneurysms in a patient with Seckel syndrome. Childs Nerv Syst ChNS Off J Int Soc Pediatr Neurosurg 14:8284. https://doi.org/10.1007/s003810050181

8. Mann TP, Russell A (1959) Study of a microcephalic midget of extreme type. Proc R Soc Med 52:1024-1027

9. Abney-Roberts SE, Parks F (2013) Seckel syndrome and pregnancy: the importance of a multidisciplinary team meeting. J Obstet Gynecol Neonatal Nurs 42:S100-S101. https://doi.org/ 10.1111/1552-6909.12199

10. Abohelwa M, Elmassry M, Iskandir M et al (2021) Seckel syndrome presenting with complete heart block. Bayl Univ Med Cent Proc 34:405-406. https://doi.org/10.1080/08998280.2020.1871265

11. Abou-Zahr F, Bejjani B, Kruyt FA et al (1999) Normal expression of the Fanconi anemia proteins FAA and FAC and sensitivity to mitomycin $\mathrm{C}$ in two patients with Seckel syndrome. Am J Med Genet 83:388-391. https://doi.org/10.1002/(sici) 1096-8628(19990423)83:5\%3c388::aid-ajmg9\%3e3.0.co;2-1

12. Adiyaman P, Berberoğlu M, Aycan Z et al (2004) Seckel-like syndrome: a patient with precocious puberty associated with nonclassical congenital adrenal hyperplasia. J Pediatr Endocrinol Metab JPEM 17:105-110. https://doi.org/10.1515/jpem.2004.17.1.105

13. Agha Z, Iqbal Z, Azam M et al (2014) A complex microcephaly syndrome in a Pakistani family associated with a novel missense mutation in RBBP8 and a heterozygous deletion in NRXN1. Gene 538:30-35. https://doi.org/10.1016/j.gene.2014.01.027

14. Aktas Z, Yuksel N, Kula S et al (2013) Childhood glaucoma as an ophthalmic manifestation of Seckel syndrome. J Glaucoma 22:e3-4. https://doi.org/10.1097/IJG.0b013e318237cadf

15. Al-Dosari MS, Shaheen R, Colak D, Alkuraya FS (2010) Novel CENPJ mutation causes Seckel syndrome. J Med Genet 47:411414. https://doi.org/10.1136/jmg.2009.076646

16. Anderson CE, Wallerstein R, Zamerowski ST et al (1997) Ring chromosome 4 mosaicism coincidence of oligomeganephronia and signs of Seckel syndrome. Am J Med Genet 72:281-285

17. Arora S, Ghai B, Rattan V (2012) Anesthetic management of a child with Seckel syndrome for multiple extractions and restoration of teeth. J Anaesthesiol Clin Pharmacol 28:398-399. https:// doi.org/10.4103/0970-9185.98361

18. Arslan D, Cimen D, Guvenc O et al (2014) A case of Seckel syndrome with tricuspid atresia. Genet Couns Geneva Switz 25:171-175

19. Aslan Y, Aynaci FM, Baki A et al (1992) (1995) Seckel's syndrome associated with congenital cystic adenomatoid malformation of the lung. Acta Paediatr Oslo Nor 84:839-840. https://doi. org/10.1111/j.1651-2227.1995.tb13774.x

20. Atalar M (2018) Cranial MRI findings in a case with Seckel syndrome. Cumhur Med J. https://doi.org/10.7197/223.vi.417787

21. Birkebaek NH, Wolthers OD, Heuch C et al (2011) Growth hormone treatment, final height, insulin-like growth factors, ghrelin, and adiponectin in four siblings with Seckel syndrome. J Pediatr Endocrinol Metab JPEM 24:995-1000. https://doi.org/10.1515/ jpem.2011.369

22. Bobabilla-Morales L, Corona-Rivera A, Corona-Rivera JR et al (2003) Chromosome instability induced in vitro with mitomycin C in five Seckel syndrome patients. Am J Med Genet A 123A:148-152. https://doi.org/10.1002/ajmg.a.20341

23. Børglum AD, Balslev T, Haagerup A et al (2001) A new locus for Seckel syndrome on chromosome 18p11.31-q11.2. Eur J Hum Genet EJHG 9:753-757. https://doi.org/10.1038/sj.ejhg.5200701
24. Boscherini B, Iannaccone G, La Cauza C et al (1981) Intrauterine growth retardation. A report of two cases with bird-headed appearance, skeletal changes and peripheral GH resistance. Eur J Pediatr 137:237-242. https://doi.org/10.1007/BF00441325

25. Brackeen A, Babb-Tarbox M, Smith J (2007) Pigmentary changes and atopic dermatitis in a patient with Seckel syndrome. Pediatr Dermatol 24:53-56. https://doi.org/10.1111/j.1525-1470.2007.00334.x

26. Buebel MS, Salinas CF, Pai GS et al (1996) A new Seckel-like syndrome of primordial dwarfism. Am J Med Genet 64:447452. https://doi.org/10.1002/(SICI)1096-8628(19960823)64:3\% 3c447::AID-AJMG1\%3e3.0.CO;2-M

27. Butler MG, Hall BD, Maclean RN, Lozzio CB (1987) Do some patients with Seckel syndrome have hematological problems and/ or chromosome breakage? Am J Med Genet 27:645-649. https:// doi.org/10.1002/ajmg.1320270318

28. Can E, Bulbul A, Uslu S et al (2010) A case of Seckel syndrome with Tetralogy of Fallot. Genet Couns Geneva Switz 21:49-51

29. Capovilla G, Lorenzetti ME, Montagnini A et al (2001) Seckel's syndrome and malformations of cortical development: report of three new cases and review of the literature. J Child Neurol 16:382-386. https://doi.org/10.1177/088307380101600516

30. Carfagnini F, Tani G, Ambrosetto P (1999) MR findings in Seckel's syndrome: report of a case. Pediatr Radiol 29:849-850. https://doi.org/10.1007/s002470050711

31. Çelenk F, Cevizci R, Altınyay Ş, Bayazıt YA (2015) Cochlear implantation in extraordinary cases. Balk Med J 32:208-213. https://doi.org/10.5152/balkanmedj.2015.15937

32. Chanan-Khan A, Holkova B, Perle MA, et al (2003) T-cell clonality and myelodysplasia without chromosomal fragility in a patient with features of Seckel syndrome. Haematologica 88:ECR14

33. Darrigo LG, Rodrigues MC, Pieroni F et al (2014) Successful outcome of allogeneic stem cell transplantation in Seckel syndrome. Pediatr Transplant 18:E93-95. https://doi.org/10.1111/ petr. 12230

34. De Coster PJ, Verbeeck RMH, Holthaus V et al (2006) Seckel syndrome associated with oligodontia, microdontia, enamel hypoplasia, delayed eruption, and dentin dysmineralization: a new variant? J Oral Pathol Med Off Publ Int Assoc Oral Pathol Am Acad Oral Pathol 35:639-641. https://doi.org/10.1111/j. 1600-0714.2006.00462.x

35. Demiralp G, Mayhew J (2007) Anesthesia in a child with Seckel syndrome. Paediatr Anaesth 17:1121. https://doi.org/10.1111/j. 1460-9592.2007.02337.x

36. Deniz K, Kontaş O, akçakuş M, (2006) Neonatal hepatitis in 2 siblings with Seckel syndrome. Pediatr Dev Pathol Off J Soc Pediatr Pathol Paediatr Pathol Soc 9:81-85. https://doi.org/10. 2350/07-05-0075.1

37. Di Blasi S, Belvedere M, Pintacuda S et al (1993) Seckel's syndrome: a case report. J Med 24:75-96

38. Dias E, Doralli P, Deeksha A, M. Zulqarnain (2017) Seckel syndrome in a 9 year old child. https://doi.org/10.5281/ZENODO.571426

39. Dinçer T, Yorgancioğlu-Budak G, Ölmez A et al (2017) Analysis of centrosome and DNA damage response in PLK4 associated Seckel syndrome. Eur J Hum Genet EJHG 25:1118-1125. https:// doi.org/10.1038/ejhg.2017.120

40. Dohlsten M, Carlsson R, Hedlund G et al (1986) Immunological abnormalities in a child with constitutional aplastic anemia. Pediatr Hematol Oncol 3:89-96. https://doi.org/10. 3109/08880018609031204

41. Erdogan S, Oto A, Bosnak M (2016) A case of Seckel syndrome with human bocavirus infection and respiratory failure / human bocavirus Enfeksiyonu Olan ve Solunum Yetmezligi Gelisen Seckel Sendromu Olgusu. J Turgut Ozal Med Cent 23:439. https://doi.org/10.5455/jtomc.2015.11.038 
42. Espérou-Bourdeau H, Leblanc T, Schaison G, Gluckman E (1993) Aplastic anemia associated with "bird-headed" dwarfism (Seckel syndrome). Nouv Rev Fr Hematol 35:99-100

43. Faienza MF, Acquafredda A, D’Aniello M et al (2013) Effect of recombinant insulin-like growth factor-1 treatment on shortterm linear growth in a child with Majewski osteodysplastic primordial dwarfism type II and hepatic insufficiency. J Pediatr Endocrinol Metab JPEM 26:771-774. https://doi.org/10.1515/ jpem-2012-0397

44. Faivre L, Le Merrer M, Lyonnet S et al (2002) Clinical and genetic heterogeneity of Seckel syndrome. Am J Med Genet 112:379-383. https://doi.org/10.1002/ajmg.10677

45. Fathizadeh A, Soltani K, Medenica M, Lorincz AL (1979) Pigmentary changes in Seckel's syndrome. J Am Acad Dermatol 1:52-54. https://doi.org/10.1016/s0190-9622(79)70004-1

46. Garg R, Uppal S, Mittal R et al (2012) Palatoplasty in a patient with Seckel syndrome. Ann Maxillofac Surg 2:63-65. https://doi. org/10.4103/2231-0746.95324

47. Goodship J, Gill H, Carter J et al (2000) Autozygosity mapping of a seckel syndrome locus to chromosome 3q22. 1-q24. Am J Hum Genet 67:498-503. https://doi.org/10.1086/303023

48. Grewal A, Sood D, Bhatia N et al (2014) Palatoplasty in a patient with Seckel syndrome: an anesthetic challenge. Braz J Anesthesiol Elsevier 64:216-218. https://doi.org/10.1016/j.bjane.2013. 08.005

49. Guirgis MF, Lam BL, Howard CW (2001) Ocular manifestations of Seckel syndrome. Am J Ophthalmol 132:596-597. https://doi. org/10.1016/s0002-9394(01)01046-7

50. Gunesli A, Andic C, Alkan O et al (2018) Endovascular treatment of a patient with moyamoya disease and Seckel syndrome: a case report. J Pediatr Neurosci 13:245-248. https://doi.org/10.4103/ jpn.JPN_96_17

51. Gürkan Y, Hosten T, Dayioglu H et al (2006) Anesthesia for Seckel syndrome. Paediatr Anaesth 16:359-360. https://doi.org/ 10.1111/j.1460-9592.2005.01798.x

52. Harper RG, Orti E, Baker RK (1967) Bird-beaded dwarfs (Seckel's syndrome). A familial pattern of developmental, dental, skeletal, genital, and central nervous system anomalies. J Pediatr 70:799-804. https://doi.org/10.1016/s0022-3476(67)80334-2

53. Harsha Vardhan BG, Muthu MS, Saraswathi K, Koteeswaran D (2007) Bird-headed dwarf of Seckel. J Indian Soc Pedod Prev Dent 25(Suppl):S8-9

54. Hatice Özış1k (2017) A case report of Seckel syndrome

55. Hayani A, Suarez CR, Molnar Z et al (1994) Acute myeloid leukaemia in a patient with Seckel syndrome. J Med Genet 31:148149. https://doi.org/10.1136/jmg.31.2.148

56. Hopkins TE, Haines SJ (2003) Rapid development of Chiari I malformation in an infant with Seckel syndrome and craniosynostosis. Case report and review of the literature. J Neurosurg 98:1113-1115. https://doi.org/10.3171/jns.2003.98.5.1113

57. Houni A, D'Souza S (2012) One lung ventilation in a patient with Seckel Syndrome. Sch Works

58. Jung M, Rai A, Wang L et al (2018) Nephrolithiasis in a 17-year-old male with Seckel syndrome and horseshoe kidneys: case report and review of the literature. Urology 120:241-243. https:// doi.org/10.1016/j.urology.2018.05.023

59. Kalay E, Yigit G, Aslan Y et al (2011) CEP152 is a genome maintenance protein disrupted in Seckel syndrome. Nat Genet 43:23-26. https://doi.org/10.1038/ng.725

60. Kazmi M, Aslam S, Mirza S, Aziz S (2016) Seckel syndrome: in a two and a half months old male presenting at tertiary care hospital in Karachi. undefined

61. Kebapci N, Efe B, Yakut A et al (2009) Dwarfism and female extenal genitalia due to congenital partial hypopituitarism in a
46XY Seckel syndrome with microcephaly and multiple skeletal deformities. Endocr Abstr 20:

62. Kebapci N, Onbasi K, Yorulmaz G et al (2009) Possible effects of IGF-1 and IGF-3 in the development of growth failure, type 2 diabetes mellitus and severe insulin resistance in a case of Seckel syndrome. Endocr Abstr 20:

63. Kilic A, Çakmak SK, Tuncali T et al (2015) Seckel syndrome with cutaneous pigmentary changes: two siblings and a review of the literature. Postepy Dermatol Alergol 32:470-474. https://doi.org/10.5114/pdia.2015.56102

64. Kim MA, Lee S, Chung HJ (2009) A case of diffuse cerebral cortical dysplasia and partial agenesis of corpus callosum in Seckel syndrome. J Korean Child Neurol Soc 17:84-89

65. Kırzıoglu Z, Erturk M, Erdoğan Y (2011) Craniofacial morphology and dental findings of Seckel syndrome: case reports of two siblings. undefined

66. Krishna AG, Scrimgeour EM, Zawawi TH (1994) Seckel syndrome in a Yemeni family in Saudi Arabia. Am J Med Genet 51:224-227. https://doi.org/10.1002/ajmg.1320510310

67. Krzyżanowska-Berkowska P, Szumny D, Młyńczak T et al (2014) Bilateral retinal detachment in Seckel syndrome. Can J Ophthalmol J Can Ophtalmol 49:e130-131. https://doi.org/10. 1016/j.jcjo.2014.07.013

68. Kumar R, Rawal M, Agarwal S, Gathwala G (2008) Semilobar holoprosencephaly in Seckel syndrome. Indian J Pediatr 75:519-520. https://doi.org/10.1007/s12098-008-0083-9

69. Lilleyman JS (1984) Constitutional hypoplastic anemia associated with familial "bird-headed" dwarfism (Seckel syndrome). Am J Pediatr Hematol Oncol 6:207-209

70. Lim KH, Wong HB (1973) Ocular anomalies in Seckel's syndrome. Aust N Z J Med 3:520-522. https://doi.org/10.1111/j. 1445-5994.1973.tb03132.x

71. Llorens-Agost M, Luessing J, van Beneden A et al (2018) Analysis of novel missense ATR mutations reveals new splicing defects underlying Seckel syndrome. Hum Mutat 39:18471853. https://doi.org/10.1002/humu.23648

72. Mahesh N, Sathish S, Naidu L et al (2018) Seckel syndrome: a case report of the rare syndrome. J Dr NTR Univ Health Sci 7:223. https://doi.org/10.4103/JDRNTRUHS.JDRNTRUHS_100_14

73. Marakhonov AV, Konovalov FA, Makaov AK et al (2018) Primary microcephaly case from the Karachay-Cherkess Republic poses an additional support for microcephaly and Seckel syndrome spectrum disorders. BMC Med Genomics 11:8. https:// doi.org/10.1186/s12920-018-0326-1

74. McKusick VA, Mahloudji M, Abbott MH et al (1967) Seckel's bird-headed dwarfism*. N Engl J Med 277:279-286. https:// doi.org/10.1056/NEJM196708102770602

75. Basak M, Tapan KSM (2002) Seckel syndrome. https://www. indianpediatrics.net/dec2002/dec-1166.htm. Accessed 5 Jun 2021

76. Millichap JG (2012) Seckel syndrome with holoprosencephaly. Pediatr Neurol Briefs 26:32. https://doi.org/10.15844/pedneurbriefs-26-4-8

77. Mo K, Vn N, Sa U et al (2015) Is the novel SCKL3 at 14q23 the predominant Seckel locus? Eur J Hum Genet EJHG 23:140. https://doi.org/10.1038/ejhg.2014.258

78. Shaheen R, Faqeih E, Ansari S et al (2014) Genomic analysis of primordial dwarfism reveals novel disease genes. Genome Res 24:291-299. https://doi.org/10.1101/gr.160572.113

79. Mokrani-Benhelli H, Gaillard L, Biasutto P et al (2013) Primary microcephaly, impaired DNA replication, and genomic instability caused by compound heterozygous ATR mutations. Hum Mutat 34:374-384. https://doi.org/10.1002/humu.22245

80. Murthy J, Seshadri KG, Ramanan PV et al (2004) A case of cleft lip and palate associated with Seckel syndrome. Cleft 
Palate-Craniofacial J Off Publ Am Cleft Palate-Craniofacial Assoc 41:202-205. https://doi.org/10.1597/02-087

81. Nihill P, Lin LY, Salzmann LB, Stevens S (1996) Esthetic overdenture for a patient with possible Seckel syndrome. Spec Care Dent Off Publ Am Assoc Hosp Dent Acad Dent Handicap Am Soc Geriatr Dent 16:210-213. https://doi.org/10.1111/j.17544505.1996.tb00862.x

82. Ogi T, Walker S, Stiff T et al (2012) Identification of the first ATRIP-deficient patient and novel mutations in ATR define a clinical spectrum for ATR-ATRIP Seckel Syndrome. PLoS Genet 8:e1002945. https://doi.org/10.1371/journal.pgen.1002945

83. Onder A, Cogulu O, Ekmekci A et al (2007) Seckel syndrome with Morgagni hernia. Clin Dysmorphol 16:209-210. https://doi. org/10.1097/MCD.0b013e3281c9b08e

84. Ouattara ABI, Barro M, Nacro SF et al (2020) The Seckel syndrome: a case observed in the pediatric department of the University Hospital Center Sourou Sanou (Burkina Faso). Pediatr Rep 12:8231. https://doi.org/10.4081/pr.2020.8231

85. Özkaya H, Akcan AB, Aydemır G, Kul M (2012) An unusual presentation of Seckel syndrome: fatty liver. Turk J Gastroenterol Off J Turk Soc Gastroenterol 23:621-623. https://doi.org/ 10.4318/tjg.2012.0401

86. Panigrahi I, Kaur S, Kulkarni K et al (2009) Seckel syndrome with chromosomal 18 deletion. Indian J Pediatr 76:1270-1271. https://doi.org/10.1007/s12098-009-0223-x

87. Poznanski AK, Iannaccone G, Pasquino AM, Boscherini B (1983) Radiological findings in the hand in Seckel syndrome (bird-headed dwarfism). Pediatr Radiol 13:19-24. https://doi.org/ 10.1007/BF00975661

88. Rajamani A, Kamat V, Murthy J, Hussain SA (2005) Anesthesia for cleft lip surgery in a child with Seckel syndrome-a case report. Paediatr Anaesth 15:338-341. https://doi.org/10.1111/j. 1460-9592.2005.01428.x

89. Ramalingam K, Kaliyamurthy SD, Govindarajan M, Swathi S (2012) Seckel syndrome: a report of a case. J Indian Soc Pedod Prev Dent 30:258-261. https://doi.org/10.4103/0970-4388. 105021

90. Ramasamy C, Satheesh S, Selvaraj R (2015) Seckel syndrome with severe sinus bradycardia. Indian J Pediatr 82:292-293. https://doi.org/10.1007/s12098-014-1568-3

91. Rao VG, Deshpande GA, Rao GS, Rehman PG (1970) Cataract in Seckel syndrome. Asian J Ophthalmol 13:12-15. https://doi. org/10.35119/asjoo.v13i1.19

92. Rayburg M, Davies SM, Mehta PA et al (2008) Successful reduced-intensity bone marrow transplantation in a patient with bone marrow failure associated with Seckel syndrome. Br J Haematol 142:675-676. https://doi.org/10.1111/j.1365-2141.2008. 07239.x

93. Reddy S, Starr C (2007) Seckel syndrome and spontaneously dislocated lenses. J Cataract Refract Surg 33:910-912. https:// doi.org/10.1016/j.jcrs.2006.12.027

94. Regen A, Nelson LP, Woo S-B (2010) Dental manifestations associated with Seckel syndrome type II: a case report. Pediatr Dent 32:445-450

95. Robbin DS (1985) Seckel's syndrome with pseudopolycoria. Ophthalmic Paediatr Genet 6:135-139. https://doi.org/10.3109/ 13816818509087632

96. Rubbini L, Preti P, Sudanese A, Brillante C (1991) Seckel's syndrome: presentation of one case associated with LeggCalvé-Perthes disease. Chir Organi Mov 76:193-195

97. Saeidi M, Shahbandari M (2020) A child with Seckel syndrome and arterial stenosis: case report and literature review. Int Med Case Rep J 13:159-163. https://doi.org/10.2147/IMCRJ.S241601

98. Sarici D, Akin MA, Kara A et al (2012) Seckel syndrome accompanied by semilobar holoprosencephaly and arthrogryposis. Pediatr Neurol 46:189-191. https://doi.org/ 10.1016/j.pediatrneurol.2012.01.002

99. Sarsu SB, Belen B, Karakus SC, Koku N (2014) Fecalith causing intestinal obstruction in a patient with Seckel syndrome. APSP J Case Rep 5:2014-5(2):22. https://doi.org/10.21699/ ajcr.v5i2.139

100. Sauk JJ, Litt R, Espiritu CE, Delaney JR (1973) Familial birdheaded dwarfism (Seckel's syndrome). J Med Genet 10:196198. https://doi.org/10.1136/jmg.10.2.196

101. Schmidt A, Chakravarty A, Brommer E et al (2002) Growth failure in a child showing characteristics of Seckel syndrome: possible effects of IGF-I and endogenous IGFBP-3. Clin Endocrinol (Oxf) 57:293-299. https://doi.org/10.1046/j.1365-2265. 2002.01590.x

102. Schmitt HP, Sergi C (2000) The central nervous system in microcephalic primordial dwarfism: is there a characteristic developmental brain pathology in Seckel or Seckel-like syndrome? Congenit Anom 40:32-39. https://doi.org/10.1111/j. 1741-4520.2000.tb00906.x

103. Seymen F, Tuna B, Kayserili H (2002) Seckel syndrome: report of a case. J Clin Pediatr Dent 26:305-309. https://doi.org/10. 17796/jcpd.26.3.102834m2827m0132

104. Shaheen R, Al Tala S, Almoisheer A, Alkuraya FS (2014) Mutation in PLK4, encoding a master regulator of centriole formation, defines a novel locus for primordial dwarfism. J Med Genet 51:814-816. https://doi.org/10.1136/jmedgenet-2014-102790

105. Shanske A, Caride DG, Menasse-Palmer L et al (1997) Central nervous system anomalies in Seckel syndrome: report of a new family and review of the literature. Am J Med Genet 70:155-158. https://doi.org/10.1002/(sici)1096-8628(19970516)70:2\%3c155:: aid-ajmg $10 \% 3 \mathrm{e} 3.0 . \mathrm{co} ; 2-\mathrm{i}$

106. Sisodia R, Raj RKS, Goel V (2014) Seckel syndrome: a rare case report. J Indian Soc Pedod Prev Dent 32:160-163. https://doi.org/ 10.4103/0970-4388.130983

107. Sommer A (2007) Photo essay-Seckel syndrome. Am J Med Genet C Semin Med Genet 145C:230-231. https://doi.org/10. 1002/ajmg.c. 30144

108. Sophie S, Ahmed T (2006) Dialysis access surgery with Seckel syndrome. Paediatr Anaesth 16:804-805; author reply 805-806. https://doi.org/10.1111/j.1460-9592.2006.01928.x

109. Stoppoloni G, Stabile M, Rinaldi MM et al (1992) Seckel syndrome: report of three sibships with the type I primordial dwarfism. Possible linkage with HLA locus. Ann Genet 35:213-216

110. Sugio Y, Tsukahara M, Kajii T (1993) Two Japanese cases with microcephalic primordial dwarfism: classical Seckel syndrome and osteodysplastic primordial dwarfism type II. Jpn J Hum Genet 38:209-217. https://doi.org/10.1007/BF01883712

111. Syrrou M, Georgiou I, Paschopoulos M, Lolis D (1995) Seckel syndrome in a family with three affected children and hematological manifestations associated with chromosome instability. Genet Couns Geneva Switz 6:37-41

112. Szalay GC (1964) Intrauterine growth retardation versus Silver's syndrome. J Pediatr 64:234-240. https://doi.org/10.1016/s00223476(64)80267-5

113. Tatar A, Ocak Z, Doneray H (2008) Seckel syndrome with spontaneous chromosomal instability. undefined

114. Teleanu R, Plesca D, Lazar A, et al (2006) Seckel syndrome and epilepsy. Neuropediatrics 37:s-2006-943694. https://doi. org/10.1055/s-2006-943694

115. Thapa R, Mallick D, Biswas B, Ghosh A (2010) Open and closed lip schizencephaly in Seckel syndrome: a case report. J Child Neurol 25:494-496. https://doi.org/10.1177/0883073809338873

116. Thapa R, Mukherjee K (2010) Seckel syndrome with asymptomatic tonsillar herniation and congenital mirror movements. J Child Neurol 25:231-233. https://doi.org/10.1177/0883073809332694 
117. Tsuchiya H, Kobayashi S, Cervenka J et al (1981) Analysis of the dentition and orofacial skeleton in Seckel's bird-headed dwarfism. J Maxillofac Surg 9:170-175. https://doi.org/10. 1016/s0301-0503(81)80038-0

118. Ucar B, Kilic Z, Dinleyici EC et al (2004) Seckel syndrome associated with atrioventricular canal defect: a case report. Clin Dysmorphol 13:53-55. https://doi.org/10.1097/00019605200401000-00017

119. Unal Y, Dogan AT, Ozkose Z, Koksal F (2008) Anesthetic management of a patient with Seckel syndrome and implanted pacemaker. Paediatr Anaesth 18:676-677. https://doi.org/10. 1111/j.1460-9592.2008.02517.x

120. Vincenzo B (2011) Eye-hand coordination in Seckel syndrome. 6

121. Wang P, Spielberger RT, Thangavelu $M$ et al (1997) dic $(5 ; 17)$ : a recurring abnormality in malignant myeloid disorders associated with mutations of TP53. Genes Chromosomes Cancer 20:282-291. https://doi.org/10.1002/(sici)1098-2264(199711) 20:3\%3c282::aid-gcc9\%3e3.0.co;2-z

122. Woods CG, Leversha M, Rogers JG (1995) Severe intrauterine growth retardation with increased mitomycin $\mathrm{C}$ sensitivity: a further chromosome breakage syndrome. J Med Genet 32:301-305. https://doi.org/10.1136/jmg.32.4.301

123. Yigit G, Brown KE, Kayserili H et al (2015) Mutations in CDK5RAP2 cause Seckel syndrome. Mol Genet Genomic Med 3:467-480. https://doi.org/10.1002/mgg3.158

124. Yoon JW, Lim JW, Cheon EJ et al (2007) A case of cerebral dystrophy and cerebellar atropy in Seckel syndrome. J Korean Child Neurol Soc 15:121-125

125. Malino, Imanuel Yuluis, Made Arimbawa, Bikin Suryawan (2013) Seckel syndrome in a - 2 year old girll Medicina. 44

126. Al-Mosawi A (2020) Virchow Seckel syndrome: the first case in Iraq and the early documentation of the syndrome in the literature. https://doi.org/10.5281/ZENODO.3887552

127. Inaloo S, Khorshidi S, Jalli R, Haghbin S (2016) Seckel syndrome and vasculopathy: a case report. J Pediatr Neurol 14:122-125. https://doi.org/10.1055/s-0036-1584278

128. Majewski F, Goecke T (1982) Studies of microcephalic primordial dwarfism I: approach to a delineation of the Seckel syndrome. Am J Med Genet 12:7-21. https://doi.org/10.1002/ajmg.1320120103

129. Fujimura M, Bang OY, Kim JS (2016) Moyamoya disease Front Neurol Neurosci 40:204-220. https://doi.org/10.1159/000448314

130. Seckel HPG Studies in Developmental Anthropology Including Human Proportions. 8

131. Willems M, Geneviève $\mathrm{D}$, Borck $\mathrm{G}$ et al (2010) Molecular analysis of pericentrin gene (PCNT) in a series of 24 Seckel/microcephalic osteodysplastic primordial dwarfism type II (MOPD II) families. J Med Genet 47:797-802. https://doi.org/10.1136/jmg. 2009.067298

132. Thompson E, Pembrey M (1985) Seckel syndrome: an overdiagnosed syndrome. J Med Genet 22:192-201. https://doi.org/10. 1136/jmg.22.3.192

133. Kim JS (2016) Moyamoya disease: epidemiology, clinical features, and diagnosis. J Stroke 18:2-11. https://doi.org/10.5853/jos.2015. 01627
134. Suzuki J, Takaku A (1969) Cerebrovascular "moyamoya" disease. Disease showing abnormal net-like vessels in base of brain. Arch Neurol 20:288-299. https://doi.org/10.1001/ archneur.1969.00480090076012

135. Scott RM, Smith JL, Robertson RL et al (2004) Long-term outcome in children with moyamoya syndrome after cranial revascularization by pial synangiosis. J Neurosurg 100:142-149. https:// doi.org/10.3171/ped.2004.100.2.0142

136. Levy ML, Levy DM, Manna B (2020) Pediatric cerebral aneurysm. In: StatPearls. StatPearls Publishing, Treasure Island (FL)

137. Yang M, Wang S, Zhao Y, Zhao J (2008) Management of intracranial aneurysm in children: clipped and coiled. Childs Nerv Syst ChNS Off J Int Soc Pediatr Neurosurg 24:1005-1012. https://doi. org/10.1007/s00381-008-0618-4

138. Deora H, Rao KVLN, Somanna S et al (2017) Surgically managed pediatric intracranial aneurysms: how different are they from adult intracranial aneurysms? Pediatr Neurosurg 52:313317. https://doi.org/10.1159/000477815

139. Perry LD, Robertson F, Ganesan V (2013) Screening for cerebrovascular disease in Microcephalic Osteodysplastic Primordial Dwarfism Type II (MOPD II): an evidence-based proposal. Pediatr Neurol 48:294-298. https://doi.org/10.1016/j.pediatrneurol.2012. 12.010

140. Bober MB, Khan N, Kaplan J et al (2010) Majewski osteodysplastic primordial dwarfism type II (MOPD II): expanding the vascular phenotype. Am J Med Genet A 152A:960-965. https:// doi.org/10.1002/ajmg.a.33252

141. Han DH, Nam DH, Oh CW (1997) Moyamoya disease in adults: characteristics of clinical presentation and outcome after encephalo-duroarterio-synangiosis. Clin Neurol Neurosurg 99(Suppl 2):S151-155. https://doi.org/10.1016/s0303-8467(97)00058-9

142. Monteiro A, Cortez GM, Granja MF et al (2021) Intracranial aneurysms in microcephalic primordial dwarfism: a systematic review. J NeuroInterventional Surg 13:171-176. https://doi.org/ 10.1136/neurintsurg-2020-016069

143. Scott RM, Smith ER (2009) Moyamoya disease and moyamoya syndrome. N Engl J Med 360:1226-1237. https://doi.org/10. 1056/NEJMra0804622

144. Smith ER, Scott RM (2005) Surgical management of moyamoya syndrome. Skull Base Off J North Am Skull Base Soc Al 15:1526. https://doi.org/10.1055/s-2005-868160

145. Ni W, Jiang H, Xu B et al (2018) Treatment of aneurysms in patients with moyamoya disease: a 10-year single-center experience. J Neurosurg 128:1813-1822. https://doi.org/10.3171/2017.3.JNS162290

Publisher's Note Springer Nature remains neutral with regard to jurisdictional claims in published maps and institutional affiliations. 